\title{
THE EFFECT OF EMOTIONAL INTELLIGENCE AND ADVERSITY QUETIONT OF SCHOOL STUDENTS ON MATHEMATICAL LEARNING RESULTS STUDENTS OF SMP N 2 NANGGULAN
}

\author{
Pupus Winandaria ${ }^{a}$, Suparman ${ }^{\mathrm{b}}$ \\ Program Studi Pendidikan Matematika FKIP UAD \\ Jalan Ring Road Selatan, Tamanan, Banguntapan, Bantul Yogyakarta \\ aPupus.winandari@gmail.com, ${ }^{\mathrm{b}}$ suparmancict@yahoo.com
}

\begin{abstract}
Emotional intelligence and Adversity Quotient of students in SMP N 2 Nanggulan are still relatively low due to lack of sympathy, sense of responsibility, and irritability. This is thought to result in low mathematics learning outcomes. This study aims to determine: a significant influence between emotional intelligence and adversity quotient of students in school on mathematics learning outcomes of students of class VIII odd semester of SMP N 2 Nanggulan, Kulon Progo Regency 2015/2016 academic year. The population in this study were students of class VIII SMP N 2 Nanggulan, Kulon Progo Regency in the academic year 2015/2016, consisting of classes VIII A, VIII B, VIII C, totaling 96 students. Class VIII A as a trial class, Samples taken from class VIII B as experimental class 1 and class VIII $\mathrm{C}$ as experimental class 2 . The sampling technique uses saturated sampling techniques. Data collection techniques using non-test test methods. Data collection instruments in the form of questionnaires and multiple-choice questions. The data collection instrument test uses a validity test, a reliability test, and a different power test. The data analysis technique used is the prerequisite test analysis including normality test and homogeneity test, followed by hypothesis testing using $2 \times 2$ Factorial Design. Finally, use the t-test to compare the high and low average of each instrument. The results showed that: (1) there was an influence of emotional intelligence on mathematics learning outcomes, evidenced by $F_{\text {count }}=4,859439652 \geq F_{\text {table }}=4,0039$ at a significant level of $5 \%, \mathrm{db}: \mathrm{V}_{1}=1$ and $\mathrm{V}_{2}=59$, (2) there is an effect of adversity quotient on mathematics learning outcomes, evidenced by $F_{\text {count }}=6,265821956 \geq F_{\text {table }}=4,0039$ at a significant level of $5 \%, \mathrm{db}: \mathrm{V}_{1}=1$ and $\mathrm{V}_{2}=59$, (3) there is an influence of emotional intelligence and adversity quotient on mathematics learning outcomes, evidenced by $F_{\text {count }}=4,528768652 \geq F_{\text {table }}=4,0039$ at a significant level of $5 \%, \mathrm{db}: \mathrm{V}_{1}=1$ and $V_{2}=59$. Then from the results of Tukey's HSD test showed that the third treatment (low emotional intelligence and high adversity quotient) which is the lowest average learning outcomes.
\end{abstract}

Keywords: Influence, Emotional Intelligence, Adversity Quotient, Student Learning Outcomes Mathematics Outcomes.

\section{INTRODUCTION}

Education is a change in attitudes and behavior of a person or group of people in terms of human maturity through teaching and training efforts. Education is a need that must be met in the process of life. Education referred to here is formal education that is education which includes teaching and learning activities which involve the role of teacher and student, while the success or student learning outcomes are influenced by good quality of education. Because good quality education will bring students to improve learning outcomes better.

In general, the factors that influence mathematics learning outcomes are internal and external factors. Internal factors formed in students include intelligence, attitude, motivation, readiness, and maturity. While external factors are factors that come from outside the student, including family, school, community, and the environment around students. During this intelligence is considered as a major factor in one's success, including the success of students in taking education. However, taking into account the different characteristics of children, different class climate, then in an effort to achieve student learning outcomes is not enough with high intelligence, but also depends on the individual or student's condition in facing any difficulties in the learning process. In facing difficulties endurance is needed so that it can make difficulties as challenges and opportunities. The ability of individuals to deal with difficulties or unwanted conditions is called the adversity quotient. In the teaching and learning 
process, students are required to be able to overcome all the problems, difficulties and obstacles that arise at any time then the adversity quotient is considered important to have. Adversity quotient as someone's intelligence in facing difficulties or problems helps students increase their potential and live a better life. More than that adversity quotient can also be mental coaching for students to avoid psychological problems. By having an adversity quotient, students are considered more able to see from the positive side, more willing to take risks, so that demands and expectations are used as support and presence in the classroom is an opportunity to provide the best learning outcomes. Students who want to know the level of adversity quotient they have, they must do an adversity quotient test. Based on information obtained from the counseling teacher at SMP N 2 Nanggulan, the school has never held an adversity quotient test. Education is a change in attitudes and behavior of a person or group of people in terms of human maturity through teaching and training efforts. Education is a need that must be met in the process of life. Education referred to here is formal education that is education which includes teaching and learning activities which involve the role of teacher and student, while the success or student learning outcomes are influenced by good quality of education. Because good quality education will bring students to improve learning outcomes better.

In general, the factors that influence mathematics learning outcomes are internal and external factors. Internal factors formed in students include intelligence, attitude, motivation, readiness, and maturity. While external factors are factors that come from outside the student, including family, school, community, and the environment around students. During this intelligence, intelligence is considered as a major factor in one's success, including the success of students in taking education. However, taking into account the different characteristics of children, different class climate, then in an effort to achieve student learning outcomes is not enough with high intelligence, but also depends on the individual or student's condition in facing any difficulties in the learning process. In facing difficulties endurance is needed so that it can make difficulties as challenges and opportunities. The ability of individuals to deal with difficulties or unwanted conditions is called the adversity quotient. In the teaching and learning process, students are required to be able to overcome all the problems, difficulties and obstacles that arise at any time then the adversity quotient is considered important to have. Adversity quotient as someone's intelligence in facing difficulties or problems helps students increase their potential and live a better life. More than that adversity quotient can also be mental coaching for students to avoid psychological problems. By having an adversity quotient, students are considered more able to see from the positive side, more willing to take risks, so that demands and expectations are used as support and presence in the classroom is an opportunity to provide the best learning outcomes. Students who want to know the level of adversity quotient they have, they must do an adversity quotient test. Based on information obtained from the counseling teacher at SMP N 2 Nanggulan, the school has never held an adversity quotient test.

During this time many people are of the opinion that to achieve high learning achievements required Intellectual Intelligence (IQ) is also high. But according to (Uno, Hamzah: 2006) someone who has IQ is not enough, the ideal is IQ coupled with a balanced EQ. This understanding is supported by Goleman's opinion quoted by Patton that psychologists agree that IQ only supports about 20 percent of the factors that determine success, while the remaining 80 percent comes from other factors, including emotional intelligence. Emotional intelligence is a person's ability to recognize self-emotions, manage self-emotions, motivate oneself, recognize other people's emotions (empathy) and the ability to build relationships (cooperation) with others. From the results of interviews with Guidance Counseling Teachers (BK) in SMP N 2 Nanggulan, that the level of emotional intelligence of students is still low. This is indicated by the problem of fighting between students, due to the emotions of students who are still easily upset when joking. The results of an interview with the Guidance Counseling Teacher (BK) in SMP N 2 Nanggulan on 18 November 2015, he stated that the level of motivation in student learning is still low, so students are still lacking in motivating themselves. This is allegedly due to environmental and family factors, the majority of parents of students who are middle-lower status, for example, the majority of the work of parents of students are laborers and farmers, so that motivation from parents is 
still lacking and the impact on student motivation itself is low. The results of an interview with a Mathematics Teacher class VII on October 24, 2015, stated that the level of intelligence of students varies, especially in class VII they still feel afraid of the subject, especially mathematics for which the subject is still considered difficult. Students feel tense when the learning process is carried out. Some students also feel that they have no strengths in mathematics, and students feel anxious when facing exams and often worry about having a turn to come to the front of the class to work on problems. According to one of the VII Grade Mathematics Teachers in SMP N 2 Nanggulan, the average Mathematics score in the school is still low, this is indicated by the Grade 7 Examination (UKK) grade for the 2015/2016 academic year that has not produced the expected results.

The problems in this study are: 1) Student's adversity quotient in SMP N 2 Nanggulan is still lacking. 2) The level of emotional intelligence of students is still lacking. 3) Mathematics is considered as a difficult and scary subject. 4) Mathematics learning outcomes in SMP N 2 Nanggulan are still low.

The purpose of this study was to determine: 1) The presence or absence of a significant influence between emotional intelligence on mathematics learning outcomes of students of class VIII semester I of SMP N 2 Nanggulan, Kulon Progo Regency in the academic year 2015/2016. 2) The presence or absence of a significant influence between the adversity quotient of students in schools on mathematics learning outcomes of students of class VIII semester I of SMP N 2 Nanggulan, Kulon Progo Regency for the academic year 2015/2016. 3) The presence or absence of a significant influence between emotional intelligence and adversity quotient of students at school on mathematics learning outcomes of students of class VIII semester I of SMP N 2 Nanggulan, Kulon Progo Regency for the academic year 2015/2016.

\section{METHODS}

This study is classified as a quantitative study and includes a comparative study with a population of female students in class VIII odd semester of SMP N 2 Nanggulan 2016/2017 academic year consisting of 3 classes namely VIII A, VIII B, and VIII C. Sampling was carried out using saturated sampling techniques. According to Sugiyono (2011: 85) "saturation sampling is a sampling technique when all members of the population are used as samples. This is often used when the population is relatively small. "In this study class VIII A as a test class, while class VIII B and VIII C as an experimental class. Data collection techniques used were questionnaires and test methods. The questionnaire is used for variables of emotional intelligence and adversity quotient. While the test is used for mathematics learning outcome variables. The research instrument tests used were validity, different power tests, and reliability tests. Then for the prerequisite test analysis used is the normality test and homogeneity test. Data analysis for hypothesis testing uses variance analysis (ANAVA), oneparty t-test and HSD's test.

\section{RESULTS AND DISCUSSION}

\section{Test Prerequisite Analysis}

The summary of normality results can be seen in Table 1 .

Table 1. Summary of Normality Test Results

\begin{tabular}{|c|c|c|c|}
\hline Treatment & $X_{\text {count }}^{2}$ & $\boldsymbol{X}_{\text {table }}^{2}$ & Df \\
\hline Low-Low & 0,292 & 3,8414 & 1 \\
\hline Low-High & 0,077 & 3,8414 & 1 \\
\hline High-Low & 1,089 & 3,8414 & 1 \\
\hline High-High & 1,856 & 5,9915 & 2 \\
\hline
\end{tabular}

From the normality test at a significant level of $5 \%$ seen $x_{\text {count }}^{2} \leq X_{\text {table }}^{2}$, this means that the distribution of data obtained in each variable is normally distributed.

The summary of homogeneity test results can be seen in table 2 . 
Table 2. Summary of Homogeneity Test Results

\begin{tabular}{|c|c|}
\hline Treatment & Score \\
\hline$x_{\text {count }}^{2}$ & 1,97112 \\
\hline$x_{\text {table }}^{2}$ & 7,815 \\
\hline Significant level & $5 \%$ \\
\hline Df & 3 \\
\hline Status & Homogeneous \\
\hline
\end{tabular}

Homogeneity test at a significant level of $5 \%$ and degrees of freedom 3 shows that $x_{\text {count }}^{2}<$ $x_{\text {table }}^{2}$, this means that the sample is homogeneous.

\section{Hypothesis Testing}

The first hypothesis is obtained $F_{\text {count }}$ of 4,859439652 while $F_{\text {table }}$ at a significant level of $5 \%, \mathrm{db}: \mathrm{V}_{1}=1$ and $\mathrm{V}_{2}=59$ that is equal to 4.0039 . So obtained $F_{\text {count }} \geq F_{\text {table }}$, thus the first hypothesis has been tested by rejecting $\mathrm{H}_{0.1}$ and accepting $\mathrm{H}_{1.1}$. This shows that emotional intelligence affects the learning outcomes of mathematics.

The second hypothesis is obtained $F_{\text {stat }}$ of 6,265821956 while $F_{\text {table }}$ at a significant level of $5 \%, \mathrm{db}: \mathrm{V}_{1}=1$ and $\mathrm{V}_{2}=59$ that is equal to 4.0039 . So that $F_{\text {count }} \geq F_{\text {table }}$ is obtained, thus the second hypothesis is tested by rejecting $\mathrm{H}_{0.2}$ and accepting $\mathrm{H}_{1.2}$. This shows that the adversity quotient of students influences student learning outcomes in mathematics.

The third hypothesis is obtained $F_{\text {count }}$ of 4.528768652 while $F_{\text {table }}$ at $5 \%$ significance level, db: $\mathrm{V}_{1}=1$ and $\mathrm{V}_{2}=59$ that is equal to 4.0039 . So that $F_{\text {count }} \geq F_{\text {table }}$ is obtained, thus the third hypothesis has been tested by rejecting $\mathrm{H}_{(0.3)}$ and accepting $\mathrm{H}_{(1.3)}$. This shows that the emotional intelligence of students and student adversity quotient affect student learning outcomes in mathematics.

A list of ANAVA student mathematics learning outcomes can be seen in Table 3.

Table 3. List of ANAVA Mathematical Learning Outcomes

\begin{tabular}{|c|c|c|c|c|}
\hline Source of Variance & Dk & JK & RJK & F \\
\hline Average & 1 & 279997,3 & 279997,3 & \\
\hline Treatment & & & & \\
A & 1 & 994,4697 & 994,46970 & 4,8594396 \\
B & 1 & 1282,281 & 1282,2816 & 6,2658219 \\
AB & 1 & 926,7988 & 926,79887 & 4,5287686 \\
\hline Error & 59 & 12074,17 & 204,64699 & \\
\hline Total & 63 & 295275,0 & - & \\
\hline
\end{tabular}

From the t-test on the emotional intelligence variable conducted on mathematics learning outcomes with a significance level of $5 \%$, the results were obtained $t_{\text {count }}=-2,0608$ and $t_{0,05 ; 59}=1,99962$ means it $t_{\text {count }}<t_{\text {table }}$ then $\mathrm{H}_{0}$ is accepted and $\mathrm{H}_{1}$ is rejected. The conclusion is that the average mathematical learning outcomes with low emotional intelligence is greater than high emotional intelligence. While from the t-test on the adversity quotient variable that has been done on student mathematics learning outcomes, with a significant level of 5\%, the results obtained $t_{\text {count }}=2,3638$ and $t_{0,05 ; 59}=1,99962$ means it $t_{\text {count }}>t_{\text {table }}$ then $\mathrm{H}_{0}$ is rejected and $\mathrm{H}_{1}$ is accepted. The conclusion is that the average mathematics learning outcomes that have a high adversity quotient are greater than those with a low adversity quotient. The results of one party's t-test can be seen in Table 4. 
Table 4. Summary of Test Results for One Party

\begin{tabular}{|l|c|c|l|lr|}
\hline \multicolumn{1}{|c|}{ Variable } & $\boldsymbol{t}_{\text {count }}$ & $\boldsymbol{t}_{\text {table }}$ & $\begin{array}{l}\text { Significant } \\
\text { level }\end{array}$ & \multicolumn{2}{|c|}{ information } \\
\hline $\begin{array}{l}\text { Emotional } \\
\text { Intelligence }\end{array}$ & $-2,0608$ & 1,99962 & $5 \%$ & $\begin{array}{l}\text { There is no no } \\
\text { difference }\end{array}$ \\
\hline Adversity Quotient & 2,3638 & 1,99962 & $5 \%$ & $\begin{array}{l}\text { There are } \\
\text { differences }\end{array}$ \\
\hline
\end{tabular}

After anava analysis is performed if the null hypothesis (H0) is rejected. However, if the null hypothesis is accepted then the analysis after anava is not necessary, because the purpose of the analysis after anava is to find which groups are different. This is indicated by $\mathrm{F}$ arithmetic which shows the differences. If $\mathrm{F}$ arithmetic shows no difference, then the analysis after anava is not necessary. The results of the HSD Tukey test calculation can be seen in Table 5.

Table 5. Summary of Tukey's HSD Test Results

\begin{tabular}{|c|c|c|l|}
\hline $\begin{array}{c}\text { Group } \\
\text { Compared }\end{array}$ & $\begin{array}{c}\text { Different } \\
\text { Mean }\end{array}$ & HSD & \multicolumn{1}{|c|}{ Information } \\
\hline$\left|\mu_{1}-\mu_{2}\right|$ & 6,223 & 6,8093 & No significant effect \\
\hline$\left|\mu_{1}-\mu_{3}\right|$ & 14,666 & 6,8093 & Significant effect \\
\hline$\left|\mu_{1}-\mu_{4}\right|$ & 0,513 & 6,8093 & No significant effect \\
\hline$\left|\mu_{2}-\mu_{3}\right|$ & 21,58 & 6,8093 & Significant effect \\
\hline$\left|\mu_{2}-\mu_{4}\right|$ & 5,71 & 6,8093 & No significant effect \\
\hline$\left|\mu_{3}-\mu_{4}\right|$ & 15,87 & 6,8093 & Significant effect \\
\hline
\end{tabular}

\section{CONCLUSION}

1. There is a significant influence between emotional intelligence on mathematics learning outcomes of students of class VIII in the odd semester of SMP N 2 Nanggulan in the 2016/2017 school year. This can be seen from the calculations obtained $F_{\text {count }}$ of 4,859439652 while $F_{\text {table }}$ at a significant level of 5\%, db: $\mathrm{V}_{1}=1$ and $\mathrm{V}_{2}=59$ that is equal to 4.0039. So that $F_{\text {count }} \geq F_{\text {table }}$ is obtained, thus the first hypothesis has been tested by rejecting $\mathrm{H}_{0.1}$ and accepting $\mathrm{H}_{1.1}$. This shows that the emotional intelligence of students affects the learning outcomes of mathematics.

2. There is a significant influence between adversity quotient on mathematics learning outcomes for students of class VIII odd semester of SMP N 2 Nanggulan 2016/17 school year. This can be seen from the calculations obtained $F_{\text {count }}$ of 6,265821956 while $F_{\text {table }}$ is obtained at a significant level of $5 \%, \mathrm{db}: \mathrm{V}_{1}=1$ and $\mathrm{V}_{2}=59$ which is equal to 4.0039 . So that $F_{\text {count }} \geq F_{\text {table }}$ is obtained, thus the second hypothesis has been tested by rejecting $\mathrm{H}_{0.2}$ and accepting $\mathrm{H}_{1.2}$. This shows that the adversity quotient of students affects the learning outcomes of mathematics.

3. There is a significant influence between emotional intelligence and adversity quotient on the mathematics learning outcomes of students of class VIII in the odd semester of SMP N 2 Nanggulan in the academic year 2016/2017. : $\mathrm{V}_{1}=1$ and $\mathrm{V}_{2}=59$ which is 4.0039 . So that $F_{\text {count }}$ $\geq F_{\text {table }}$ is obtained, thus the third hypothesis has been tested by rejecting $\mathrm{H}_{0.3}$ and accepting $\mathrm{H}_{1.3}$. This shows that emotional intelligence and adversity quotient affect student learning outcomes in mathematics.

\section{REFERENCES}

Arikunto, Suharsimi. 2013. Prosedur penelitian Pendekatan Praktik. Jakarta: PT. Rineka Cipta. Goleman, Daniel. 1996. Emotional Intelligence. Jakarta: PT. Gramedia Pustaka Utama.

Khasanah, Uswatun. 2013. Statistika Non Paarametrik. Yogyakarta: UAD

Stoltz. 2000. Adversity Quotient Mengubah Hambatan Menjadi Peluang. Jakarta: PT. Gramedia.

Sudjana. 2002. Metode Statistika. Bandung: Tarsito.

Suparman. 2015. Metode Penelitian Pendidikan. Yogyakarta: UAD 